\title{
Some results of differentiability for the solution of an integral equations system
}

\section{MARIA DOBRIŢOIU}

\section{ABSTRACT.}

Using the fixed point theorem given by [Rus, I. A., A Fiber generalized contraction theorem and applications, Mathematica, 41(64) (1999), No. 1, 85-90] and an idea of [Sotomayor, J., Smooth dependence of solution of differential equation on initial data: a simple proof, Bol. Soc. Brasil., 4 (1973), No. 1,55-59] we establish some conditions of differentiability of the solution for the following system of integral equations:

$$
x(t)=\int_{a}^{b} K(t, s) \cdot h(s, x(s), x(a), x(b)) d s+f(t), t \in[a, b],
$$

and such we obtain two theorems of differentiability. Finally, two examples are given.

\section{REFERENCES}

[1] Ambro, M., Approximation of the solutions of an integral equation with modified argument, Stud. Univ. BabeşBolyai Math., 2 (1978), 26-32 (in Romanian)

[2] András, Sz., Fredholm-Volterra integral equations, Pure Math. Appl., 13 (2002), No. 1-2, 21-30

[3] András, Sz., Fiber $\varphi$-contractions on generalized metric spaces and applications, Mathematica, 45(68) (2003), No. $1,3-8$

[4] Berinde, V., Generalized contractions and applications, Cub Press 22, Baia Mare, 1997

[5] Coman, Gh., Rus, I., Pavel, G. and Rus, I. A., Introduction to the operational equations theory, Dacia, ClujNapoca, 1976 (in Romanian)

[6] Dobriţoiu, M., Analysis of an integral equation with modified argument, Stud. Univ. Babeş-Bolyai Math., 51 (2006), No. 1, 81-94

[7] Dobriţoiu, M., System of integral equations with modified argument, Carpathian J. Math., 24 (2008), No. 2, 26-36

[8] Dobriţoiu, M., Kecs, W. W. and Toma, A., An Application of the Fiber Generalized Contractions Theorem, WSEAS Transactions on Mathematics, Issue 12, Vol. 5, 2006, 1330-1335

[9] Dobriţoiu, M., Kecs, W. W. and Toma, A., The Differentiability of the Solution of a Nonlinear Integral Equation, Proc. of the 8th WSEAS Int. Conf. on Math. Methods and Comp. Techniques in Electrical Engineering, Bucharest, 2006, 155-158

[10] Dobriţoiu, M., Integral Equations with Modified Argument, Cluj University Press, Cluj-Napoca, 2009 (in Romanian)

[11] Dobriţoiu, M., A Nonlinear Fredholm Integral Equation, Transylv. J. Math. Mech., 1 (2009), No. 1-2, 25-32

[12] Guo, D., Lakshmikantham, V. and Liu, X., Nonlinear integral equations in abstract spaces, Kluwer, London, 1996

[13] Mureşan, V., Functional-Integral Equations, Mediamira, Cluj-Napoca, 2003

[14] Mureşan, V., A boundary value problem for some functional-differential equations, via Picard operators, Dedicated to Professor Ioan A. RUS on the occasion of his 70th anniversary, Carpathian J. Math., 23 (2007), No. 1-2, 141-148

[15] Mureşan, V., Differential equations with modified argument, via weakly Picard operators' theory, Carpathian J. Math., 29 (2013), No. 1, 53-60

[16] Perov, A. I., On the Cauchy problem for a system of ordinary differential equations, Priblijen. Metod Res. Dif. Urav., Kiev, 1964 (in Russian)

Received: 12.01.2013; In revised form: 18.04.2013; Accepted: 15.01.2014

2010 Mathematics Subject Classification. 47H10, 45G10.

Key words and phrases. System of Fredholm integral equations, solution, Picard operator, existence and uniqueness, differentiability. 
[17] Precup, R., The role of convergent to zero matrices in the study of semiliniar operator systems, Math. Comput. Modelling, 49 (2009), No. 3-4, 703-708

[18] Rus, I. A., Principles and Applications of the Fixed Point Theory, Dacia, Cluj-Napoca, 1979 (in Romanian)

[19] Rus, I. A., Generalized contractions, Seminar on Fixed Point Theory, No. 3, 1983, 1-130

[20] Rus, I. A., A Fiber generalized contraction theorem and applications, Mathematica, 41(64), (1999), No. 1, 85-90

[21] Rus, I. A., Fiber Picard operators theorem and applications, Stud. Univ. Babeş-Bolyai Math., 44 (1999), No. 3, 89-97

[22] Rus, I. A., Picard operators and applications, Sci. Math. Jpn., 58 (2003), No. 1, 191-219

[23] Rus, I. A., Petruşel, A. and Petruşel, G., Fixed Point Theory, Cluj University Press, 2008

[24] Sotomayor, J., Smooth dependence of solution of differential equation on initial data: a simple proof, Bol. Soc. Brasil., 4 (1973), No. 1, 55-59

[25] Şerban, M. A., Fibre $\varphi$-contractions, Stud. Univ. Babeş-Bolyai Math., 44 (1999), No. 3, 99-108

[26] Şerban, M. A., The fixed point theory for the operators on cartesian product, Cluj University Press, Cluj-Napoca, 2002 (in Romanian)

[27] Şerban, M. A., Application of fiber Picard operators to integral equations, Bul. Şt. Univ. Baia Mare, Seria B, Matematică-Informatică, XVIII (2002), No. 1, 119-128

[28] Şerban, M. A., Fixed point theorems on cartesian product, Fixed Point Theory, 9 (2008), No. 1, 331-350

Department of Mathematics ANd COMPUTER SCIENCE

UNIVERSITY OF PETROŞANI

UniversităţiI 2, 332006 PETroşani, Romania

E-mail address: mariadobritoiulyahoo.com 